\title{
Do American and Korean education systems converge? Tracking school reform policies and outcomes in Korea and the USA
}

\author{
Jaekyung Lee $\cdot$ Daekwon Park
}

Published online: 8 May 2014

(c) Education Research Institute, Seoul National University, Seoul, Korea 2014

\begin{abstract}
This study examines key school reform policies and outcomes of the USA and Korea over the past three decades from comparative perspectives. Since the two nations' unique educational problems brought divergent educational reform paths-standardization versus differentiation, high-stakes testing versus individualized assessment, and centralization versus decentralization-the study tracks international policy benchmarking efforts and potential impact on educational convergence. The study employs mixed methods, including the content analysis of research and media documents and the trend analysis of TIMSS and PISA datasets. The results indicate that, despite significant changes in policy discourse, the gaps between Korea and the USA in student math achievement and school climates did not narrow. The policy lessons from these cases and the issues of international education benchmarking are discussed.
\end{abstract}

Keywords Education policy - School reform · Comparative education $\cdot$ Benchmarking

In the midst of an international brain race and school accountability movement, American educational policymakers often attempted to copy policies such as national curricula and testing from higher-performing Asian countries including Korea (Baker 2003; Lee 2001). Because the

An earlier version of this paper was presented at ICER conference at Seoul National University, Seoul, Korea.

J. Lee $(\bowtie)$

University at Buffalo, SUNY, Buffalo, NY, USA

e-mail: j1224@buffalo.edu

D. Park

Seoul National University, Seoul, Korea
USA school system was viewed as fragmented and student outcomes as mediocre, American school reform focused on raising educational standards, tightening curriculum and assessment, and improving academic achievement. In contrast, policymakers in Korea, where the school system was viewed as over-standardized and the educational processes as deficient, focused on deregulating schools, diversifying curriculum and assessment, and enhancing whole-person education. Given cross-national policy benchmarking efforts, the central question is whether the different reform paths led to educational convergence between the two countries and produced desired outcomes. This study examines school reform initiatives of the USA and Korea over the past two or three decades from international comparative perspectives that shed new lights on the strengths and pitfalls of policy benchmarking.

Given cross-national benchmarking toward desired educational goals and outcomes, the central question is whether the different reform paths are leading to educational convergence between those Eastern and Western countries. In the curriculum and assessment arenas, more uniform curriculum and high-stakes assessment with a focus on academic achievement were expected in the USA, whereas more adaptive curricula and flexible assessments toward whole-person education were expected in Korea. Thus, these opposite policy measures, if implemented successfully, would make the two different systems more alike. At the same time, in the school governance arena, increased state power and decreased local district influence was expected in the USA, whereas decreased state power and increased local school board influence was expected in Korea. Combined with curriculum and assessment reforms, school governance reforms are likely to boost educational convergence. Examination of such changes in educational processes and outcomes requires more systematic and 
comprehensive data collection than the current international assessment projects which focus on academic achievement (see Lee 2001).

Many educational researchers have observed a global convergence in both educational ideology and educational structure (Meyer et al. 1979; Ramirez and Boli 1987). From a perspective of new institutionalism theory, education reforms through benchmarking may be understood as one of the "decoupling" (symbolic isomorphism) strategies toward gaining legitimacy and public confidence. The theory suggests that school systems which depend on conformity to institutionalized myths for survival often engage in a process of decoupling that buffers work in the technical core from the consequences of institutional conformity; the process is expected to gain public confidence by maintaining the appearance that things are working as they should be, even if they are not (Meyer and Rowan 1978; Rowan and Miskel 1999). Reforms that are isomorphic with the fundamental tenets of the institutional environment stand a better chance of survival than reforms that are not (Meyer and Rowan 1978; Rowan 1982; Cuban 1992). With improved educational technology and enhanced capacity to inspect educational productivity, however, school systems face a much stronger demand for technical performance improvement, but at the same time, they do not experience a decline in demands for institutional conformity (Rowan and Miskel 1999). Therefore, the question is whether changes happened to not only policy discourse and inputs but also schooling practice and student outcomes.

\section{Methods}

This study builds upon the earlier comparison of educational reform policies in four nations including Japan, Korea, England, and the USA (Lee 2001). The study involves a comparative analysis of major school reforms in two selected industrial countries, South Korea from the East and the USA from the West that differ significantly in terms of educational institutions and cultures. These two countries were also selected for their contrasting approach to school reform over the last three decades. The objective of this study is to understand the variation in school reform policies among those different countries and to explore their consequences for educational convergence. To this end, this paper combines statistical analyses of international datasets with critical review of school reform literature, related government reports, and newspaper articles. While the previous study examined only policy formulation and adoption, there was no tracking of policy implementation and impact on student outcomes and school climates. The current study employs mixed methods, including qualitative content analysis of related policy documents and media reports as well as statistical trend analysis of the 1995-2007 TIMSS and 2000-2009 PISA datasets.

For the USA, we conduct a review of past educational studies and media reports to examine the trends of research and public discourse about the issues of school reform. We search the Education Week (EW) database and Educational Resources Information Center (ERIC) database with key words "standards-based education," "high-stakes test," "performance accountability," and "school choice" to examine the trend of key policy issue coverage in research articles and reports over the past three decades. For Korea, we also conduct a comparable review of past educational studies and media reports (Korean databases) to examine the trends of research and public discourse about the issues of educational diversification, differentiation, decentralization, and student-centered education. For reviewing media coverage and academic studies with the key words "education decentralization," "education diversification," "education liberalization," "student-centered education," and "school choice," we search Korea News Integrated Database System (KINDS) and Research Information Sharing Service (RISS), respectively.

Did the Korean and American school systems become more alike as a result of these contrasting school reform policies? Did their diverging policy paths bring about some convergence of student outcomes? While the USA instituted more rigorous academic standards, and tightened school accountability requirements with high-stakes testing to improve academic achievement, Korea decentralized curriculum control and loosened testing requirements to lessen competition and enhance student-centered education. One exception was the common policy theme of school choice for both nations. If their educational reform policies had intended effects on teacher and student behaviors, Korea was expected to see more positive change with improved teacher-student relations as a result of more student-centered progressive education and teacher support. In contrast, the USA was expected to see greater improvement in school disciplinary climate through the stronger academic press under high-stakes test accountability. Further, we may expect to see changes in student outcomes as a result of their divergent policy paths: Academic achievement as measured by test scores would have improved more in the USA than in Korea, whereas students' own perception of their academic achievement would have improved more in Korea than in the USA. We explore the hypothesized relationship between policy changes, school climates, and student outcomes (Fig. 1).

This study has several limitations. First, the study examined only selected outcomes which diverging policy paths may bring about; they were restricted to students' 
Fig. 1 American and Korean education reform policy scenarios: expected changes in policy inputs and outcomes

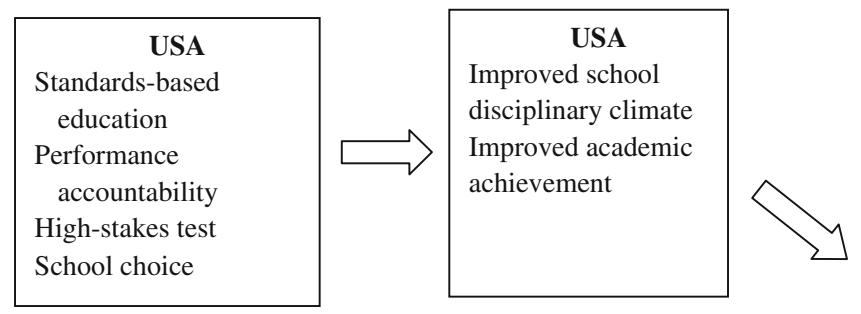

Education Reform PoliciesExpected Outcomes

\begin{tabular}{|l|l|}
\hline \multicolumn{1}{|c|}{ Korea } \\
Decentralization \\
Diversification \\
Liberalization \\
$\begin{array}{l}\text { Student- } \\
\text { centerededucation } \\
\text { School choice }\end{array}$
\end{tabular}

Did the US-Korea gaps in school climates and student attitude/achievement outcomes narrow towards educational convergence? academic achievements and school climate. Clearly, the goals of educational reform by a nation are not only for the improvement of student achievement and school climate; these might be a small part of educational reform from political perspective on the one hand and might not be necessarily dependent on educational reform at all on the other hand. Another limitation is that the reviews of education reform policies in two countries were largely descriptive rather than explanatory. Education reform policies in both countries lacked a coherent theory of action and logic model that can help guide evaluations and explain results. Subsequent studies are needed to examine the causal mechanism of educational reform policies, including the interaction between structure and actors and the role of major actors in the reform through in-depth interview and/or participatory observation. It may not be valid to attribute observed changes in student outcomes to a national education policy because many other forces may have influenced the results at the same time. Nevertheless, the analysis of student test and survey results from the past four successive rounds of TIMSS and PISA data may provide some insight into the effects of school reform policy on student outcomes.

\section{Findings}

Policy formulation and implementation

Comparison of school reform initiatives between the two different countries reveals the fact that educational reform policies share highly ambitious goals and reflect the utopian view that educational reform can change schools and advance society. In each of the study countries, education reform was initiated primarily to solve their social and/or economic problems and gained relatively wide public attention and/or support. During this process, education, specifically public school, was blamed for the broader problems including what might be beyond school control, but at the same time, reforming education was seen as a promising solution. Further, increasing media reports of international assessment and survey results such as TIMSS and PISA brought public attention to the rankings and status of each nation relative to other nations in terms of students' academic achievement as measured by test scores and their schooling conditions.

In that process, international benchmarking has emerged as a quick policy response or solution to each nation's educational problems such as low academic performance and poor student engagement in schooling. Policymakers may gain public support by adopting global standards or high-performing nation's benchmarks of best practice, while it also helps them saving potential time and cost needed for new policy search and development. As policymakers become more concerned about not only legitimacy but also productivity along with increasing demands for accountability, benchmarking may have been chosen as a strategy to meet both needs. In the USA, where lack of focus and accountability were identified as major deficiencies of their educational systems, efforts were made to standardize curriculum, tighten assessment practices, and introduce market-like competition into their public school systems. This American education policy movement involved benchmarking the hallmarks of high-performing East Asian (Japanese and Korean) school systems. Different social and educational challenges, on the other hand, resulted in policies to differentiate curriculum, diversify assessment, and decentralize school governance in Korea, 
Fig. 2 The trend of American educational research publications on key policy topics based on 1981-2010 ERIC database searches with key words "standards-based education," "high-stakes test," "performance accountability," and "school choice"

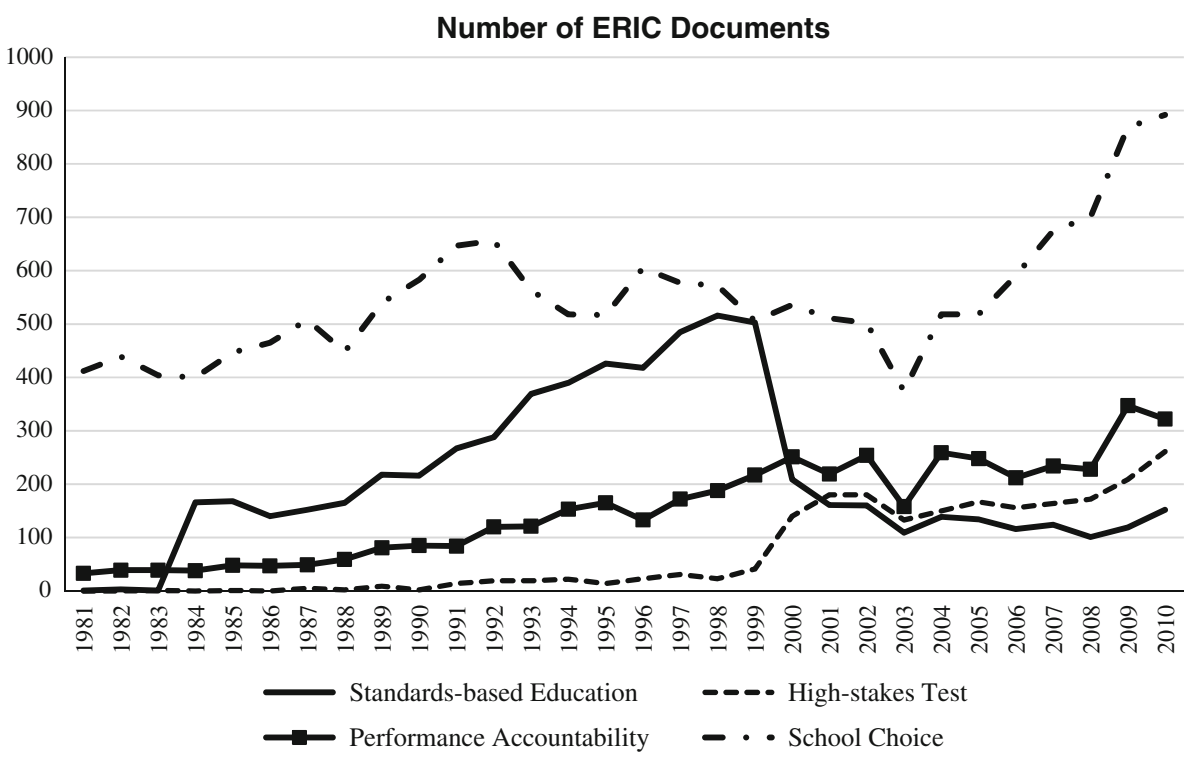

where uniform control and excessive competition were blamed for the lack of humane education despite their past contributions to academic performance and industrial development (Moon 2007). This Korean education policy movement involved benchmarking progressive and decentralized aspects of American school system.

In each of these countries, and regardless of the issues to be addressed, reports/proposals from national commissions or government agencies played catalytic roles by giving momentum and legitimacy for nationwide school reform efforts. In the USA, the National Commission on Excellence in Education, a prestigious ad hoc panel, issued A Nation at Risk in 1983, which triggered a wave of reform activity in the states (Koppich and Guthrie 1993). In Korea, the Presidential Commission on Education Reform, established in 1994, has been instrumental in education reform by producing four sequential reform proposals (Gahng 1998).

The school reform processes in those countries were not always smooth because of policy implementation barriers. Implementation of reform policies that require breaking up with traditional values and practices tends to face more severe resistance from vested interest groups and more frequent interruption or even demise subject to political changes. Indeed, the reform initiatives were under criticisms in all countries because of their radical approach to educational changes and exclusion of teachers in their topdown reform processes. In the following sections, we provide more in-depth review of education reform movement and policy discourse in each country.

\section{The case of USA education reform}

There were several major environmental changes that influenced educational reform movement during the past three decades. A quick review of educational research studies and reports over the past three decades gives a glimpse into the trends of academic and public discourse about the key issues of American education including "standards-based education," "high-stakes test," "performance accountability," and "school choice" (see Fig. 2).

A Nation at Risk created a crisis atmosphere, connecting USA economic decline with educational performance and suggesting that educational upgrading would lead to economic revitalization (National Commission on Excellence in Education 1983). The hallmark of education reform during the 1980s and 1990s can be labeled standards-based education. The key idea is to have a coherent state education policy system aimed at high academic standards for all students, specifying what the students should know and be able to do in core subject areas (Smith and O'Day 1991). As Figs. 2 and 3 show, both research publications and media reports on the issue of "standards-based education" have been on the rise since the early 1980s, possibly due to the 1983 A Nation at Risk report, and after its peak on 2000, the number of publications on that topic declined rapidly. The timing of this change with precipitous drop of standards-based education coincides with the acceleration of publications on "performance accountability" and "high-stakes test" issues.

While the research and media coverage of performance accountability was pretty stable during the 1980s, there was a sudden dramatic increase in the number of research and media reports on the topic in the early 1990s. What was the reason for this surge of accountability as a buzzword across the nation and states? When was the tipping point that testdriven or performance-driven accountability issues dominate educational policy discourse and shape educational research agenda? One significant accountability milestone 
Fig. 3 The trend of American educational media reports on key policy topics based on 1981-2010 Education Week (EW) database searches with key words "standards-based education," "high-stakes test," "performance accountability," and "school choice"
Number of EW Documents

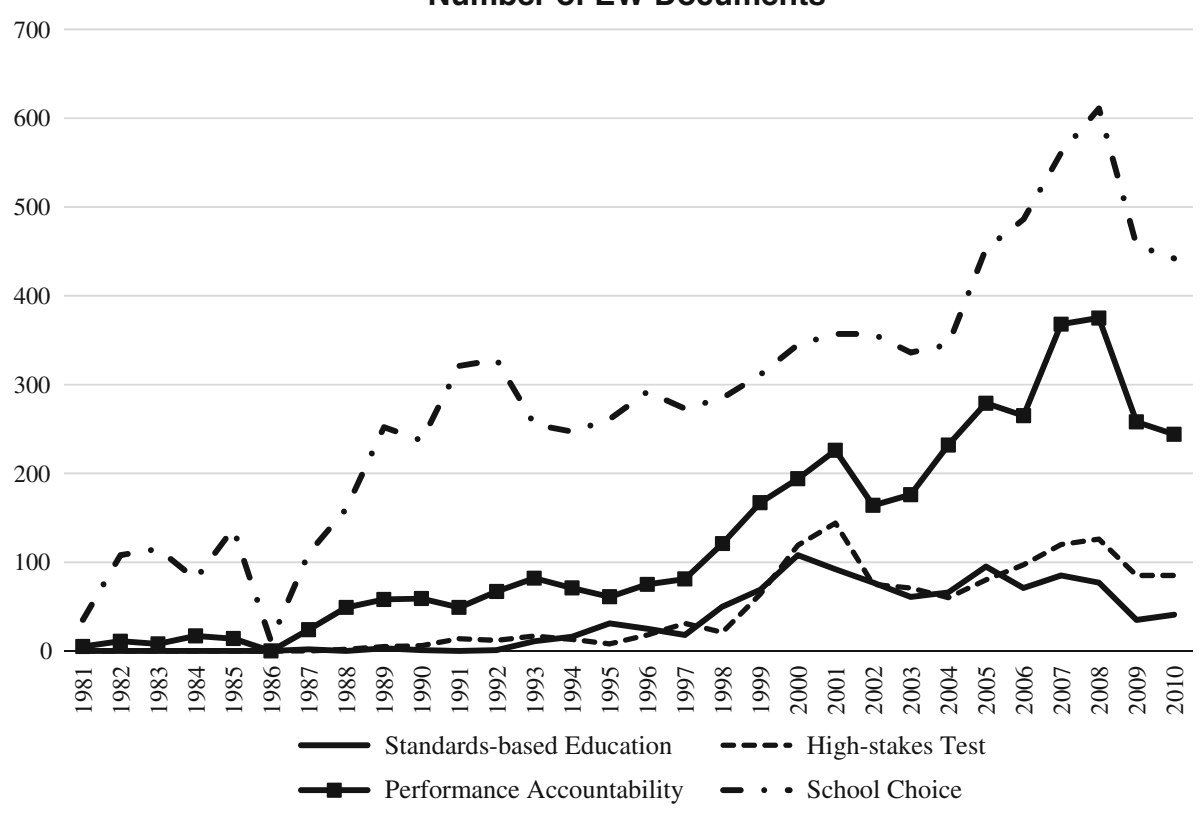

took place in 1989 at the National Education Summit of state governors to establish education goals for 2000. This Goals 2000 program was enacted into law in 1994, pushing for national standards and assessments. At the same time, the Improving America's Schools Act of 1994 (IASA), the law that reauthorizes the Elementary, and Secondary Education Act of 1965 (ESEA) reinforced the performance-based school accountability movement. Once the accountability movement got momentum, the volume of media attention and research investigation quickly increased over the last decade. With increasing concerns about poor student performance in the USA, increasing numbers of states adopted student-targeted policies such as high school exit exams during the 1990s. This movement culminates in the No Child Left Behind Act of 2001 (NCLB) that mandated statewide testing and test-based accountability policy with serious consequences for schools and teachers. Increasing focus on testing has derailed standards-based school reforms; tests rather than curriculum drove instruction. It is argued that high-stakes testing and school choice policy hijacked standards-based education movement (Ravitch 2010).

\section{The case of Korean education reform}

Korean education has expanded rapidly, elementary and secondary education has become universal, and higher education is highly accessible; the matriculation rate of higher education is $72 \%$ in 2011(Korea National Statistics Office). This remarkable educational development, enabled by national planning efforts and public investments in education, contributed to mass production of human capital and resulting economic growth. However, this growth has been accompanied by serious educational problems such as schooling becoming a tool for college entrance exam passage, huge expansion of cram schooling, and excessive government regulation of schools. Under these circumstances, the Presidential Commission on Education Reform (PCER) was established in 1994 and has been instrumental in Korean education reform (Gahng 1998; Si-gan-gwagong-gan-sa 1995). Beginning May 31, 1995, the PCER made four sequential reform proposals. For the reform of K-12 education, the proposals included new curricula for humanities and creativity, creation of autonomous school communities, and a new college admission system. While introducing more authentic student assessment, the reform requested that schools maintain a "comprehensive personal record" for each student, including all personal data and that the record be given substantial weight in the college admissions process. Each school was also required to organize a school council which involved parents and teachers in school-based decision-making. At the same time, different kinds of high schools and specialized programs were allowed to be established. To hold school districts and schools accountable, the government's administrative and financial support was linked to their performance evaluation results.

Curriculums of elementary and secondary schools in Korea have been the source of parental dissatisfaction for the lack of creativity, which emphasize memorization and regurgitation. In that sense, school reform has been targeting to change the curriculum, teacher-student relationship, and learning environment to invigorate creativity in schooling since May 31st School Reform (5.31 School Reform in short) of Kim Young Sam administration in 
1995. This reform aimed at learner-centered education, diversity of education, and education for autonomy, responsibility, freedom, and equality. It is incarnated as the seventh National Standard Curriculum of 1997 to boost the personality and the creativity as the teaching and learning's core task of schools at national level (Ministry of Education 1997). 5.31 School Reform has been the capstone of school reform movement until now even though the ruling parties have been changed twice.

The transition of education reform has been smooth despite changes in the government regime (Kim 2003). The seventh revision of the national curriculum was made in 1997, following the vision and framework of school reform envisioned by the PCER (Huh 1998). Schools could have increased time for activities that are deemed educationally appropriate for their students. However, the extent of allowed changes was minimal. In addition, differentiated curricula were introduced in which different learning contents and objectives were prepared for different groups of students. However, little effort was made to reduce class size and increase teacher support, which makes it unlikely that this measure alone could reduce the need for private tutoring. Moreover, national newspapers have reported socalled collapse (breakdown) of classrooms or desolation of education phenomena across the nation's high schools (Chosunilbo, August 23, 1999; Joongangilbo, October 20, 1999). This includes absenteeism, truancy, resistance to school authority, and challenge to teachers, apathy, and other behavioral problems observed in schools and classrooms. These problems were attributed to the low quality of instruction and student-teacher relationship in schools as well as the heavy reliance of parents and students on outof-school private tutoring practices (Kim 2003).

Under these circumstances, the education policies from subsequent administrations of Kim Dae Jung and Roh Moo Hyun followed the basic principles of 5.31 School Reform plan but pursued more aggressive measures for studentcentered education. Kim's government diversified the college admission policy to adopt performance assessment, student record, and recommendation letter as alternative criteria to the standardized tests and put weight on learnercentered open education, enhancing self-directed learning for competency building and creating new school environment for nurturing creativity and personality (Ministry of Education 1998a, b). Roh administration also aimed at diversifying the curriculum of high school education and delegated centralized regulation and authority to local and school levels. Early decision for college admission was expanded for easing students' and parents' academic and economic burden for getting the tickets to college.

Furthermore, Lee MyungBak administration set "Education for Creativity and Personality" as its national agenda and expanded the targeted students from the talented students to general students (The Board of Audit and Inspection 2012); it became ultimate goal for education of Korea and main criteria for college admission as an alternative to standardized tests which funnels human potential into cognitive domain. For example, it implemented admission officer program as one of the flagship programs of education reform policy. Under this program, most colleges and universities investigate the portfolio and performance of applicants for admission to assess their creativity rather than considering standardized college entrance test scores and school grades (Kim et al. 2010). The government also accelerated high school diversification policy that involved more specialization and privatization (Oh 2011).

President Park GuenHye administration's education platform is crystallized as "Education for happiness and for cultivating creative talent" at the annual presidential report by Ministry of Education after her inauguration in February 2013. As the incumbent administration has strengthened the idea of "restoring the fundamental of education" and "education for dream and talent," 5.31 School Reform is facing partial modification; for the first time in two decades, this administration declares the simplification of college entrance system rather than diversification. Some stream of 5.31 School Reform is expected to keep its direction, while some will take a turn to different path.

For searching the trends of academia and media's interests with education issues in last two decades, RISS and KINDS are used of reviewing academic terrain and media coverage, respectively. The key words "education decentralization," "education diversification," "education

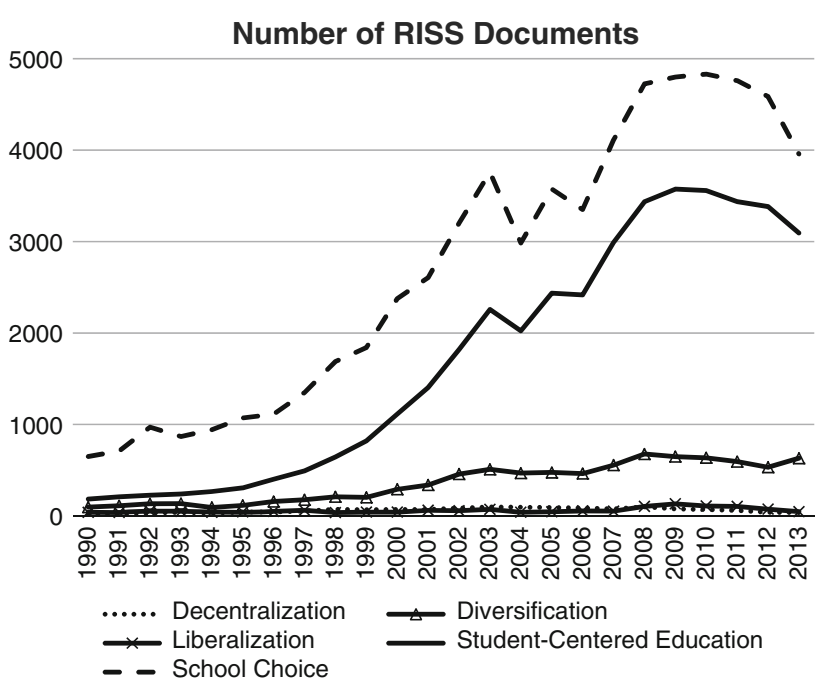

Fig. 4 The trend of educational research on key policy topics based on 1990-2013 RISS database searches with key words "education decentralization," "education diversification," "education liberalization," "student-oriented education," and "school choice" 


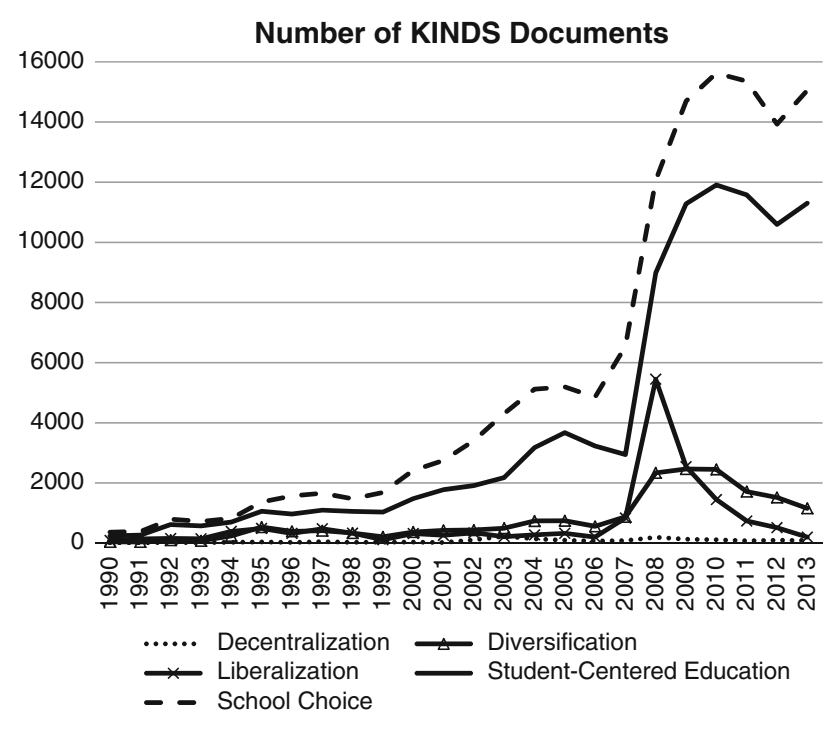

Fig. 5 The trend of media coverage on key policy topics based on 1990-2013 KINDS database searches with key words "education decentralization," "education diversification," "education liberalization," "student-oriented education," and "school choice"

liberalization," "student-centered education," and "school choice" are used for tracking research and media coverage of school reform issues in Korea (see Figs. 4, 5).

The frequency of documents that include each of the six key words has incrementally increased since middle of 1995 while facing big leap in 2007-2008; since the implementation of 5.31 School Reform at Kim Young Sam administration, the direction of school reform has not been out of rail so far. Even though there was governmental change (Grand National Party to Democratic Party) in 1998, the trends of issue appearance keep the same pattern. Through the presidential election in late 2007, the change of government (Democratic Party to Grand National Party) occurred again and strengthening or weakening the idea of 5.31 School Reform was controversial during the election. Figure 5 shows the abrupt increase in media coverage of "school choice" and "student-centered education," while that of "education liberalization" and "education diversification" was increased, but the frequency is low in 2007-2008. This reflects and confirms the Lee MyungBak administration's commitment to full-fledged implementation of 5.31 School Reform.

Figure 4 shows that there are two points of sudden increase in "school choice" and "student-centered education" in 2003 and 2008; both years are the inauguration year of then presidents, Roh Moo Hyun and Lee MyungBak. Despite their party identification, both administrations' emphasis on that issue is reflected by academic research of those years. Both Figs. 4 and 5 show that the issue of "education decentralization" keeps low coverage in academia and media. As the decentralization was
Table 1 1995-2007 TIMSS eighth-grade average math achievement trends in Korea and the USA

\begin{tabular}{llllll}
\hline \multicolumn{6}{l}{ Eighth-grade average math scores } \\
\hline Country & 1995 & 1999 & 2003 & 2007 & $1995-2007$ gain \\
Korea & 581 & 587 & 589 & 597 & $+16^{*}$ \\
USA & 492 & 502 & 504 & 508 & $+16^{*}$ \\
\hline
\end{tabular}

* The gains are statistically significant at the $p<.05$ level

Table 2 1995-2007 TIMSS eighth-grade students' self-concept of math achievement in Korea and the USA

\begin{tabular}{llllll}
\hline \multicolumn{6}{l}{ Eighth-grade self-concept of math ability/achievement } \\
\hline Country & 1995 & 1999 & 2003 & 2007 & $1995-2007$ gain \\
Korea & 38 & 38 & 43 & 44 & $+6^{*}$ \\
USA & 86 & 85 & 83 & 83 & -3 \\
\hline
\end{tabular}

Percentage of students who agreed or strongly agreed with the statement that "I usually do well in math"

Four-point Likert scale was used for response format across all years. However, in 2003 and 2007, the wording of response categories changed slightly: "Agree" changed to "Agree a little" and "Strongly agree" changed to "Agree a lot." Therefore, 1995-2007 gain in the overall percentage of students needs to be interpreted with this caveat

$*$ The gains are statistically significant at the $p<.05$ level

institutionalized after the change of selecting large city/ state school superintendent from appointment (by the Minister of Education) to public election in 1995, both academia and media pay little attention. Even though the authority and the responsibility were delegated from the central government to large city/state education agency, the schools were still following the near top-down direction.

\section{Policy outcomes: student achievement and school climate}

While educational policy discourse changed in expected directions, it is not clear whether the policy movement brought about expected changes in school practices and student outcomes (see Fig. 1). First, the TIMSS math achievement test results were not supportive of expected policy scenario about narrowing of the achievement gap between the USA and Korea (see Table 1). Korea made significant progress, with a 16-point gain in eighth-grade math over the 1995-2007 period. The USA also made the same amount of significant progress, with a 16-point math gain at grade 8 . Therefore, their national average math achievement gap has not changed at all in spite of different reform paths; the size of the gap remains as large as one standard deviation.

Second, Table 2 shows the results of TIMSS eighthgrade student survey about the perception of their own 
Table 3 PISA 2000 and 2009 15-year-old students' survey reports about teacher-student relations and disciplinary climate in Korea and the USA

\begin{tabular}{|c|c|c|c|c|c|c|}
\hline & \multicolumn{3}{|c|}{ Korea } & \multicolumn{3}{|l|}{ USA } \\
\hline & 2000 & 2009 & Gain & 2000 & 2009 & Gain \\
\hline \multicolumn{7}{|l|}{ Teacher-student relations } \\
\hline $\begin{array}{l}\text { Most of my teachers } \\
\text { really listen to what I } \\
\text { have to say }\end{array}$ & 40.7 & 57.2 & $16.5^{*}$ & 70.8 & 73.6 & 2.8 \\
\hline $\begin{array}{l}\text { If I need extra help, I } \\
\text { will receive it from } \\
\text { my teachers }\end{array}$ & 76.4 & 83.3 & $6.9^{*}$ & 82.2 & 88.4 & $6.2 *$ \\
\hline $\begin{array}{l}\text { Most of my teachers } \\
\text { treat me fairly }\end{array}$ & 66.4 & 75.3 & $8.9^{*}$ & 82.2 & 88.6 & $6.4^{*}$ \\
\hline \multicolumn{7}{|l|}{ Disciplinary climate } \\
\hline $\begin{array}{l}\text { Students don't listen to } \\
\text { what the teacher says }\end{array}$ & 67.9 & 89.9 & $22 *$ & 73.8 & 75.5 & 1.7 \\
\hline $\begin{array}{l}\text { There is noise and } \\
\text { disorder }\end{array}$ & 70.6 & 77.2 & $6.6^{*}$ & 70.2 & 72 & 1.8 \\
\hline $\begin{array}{l}\text { The teacher has to wait } \\
\text { a long time for the } \\
\text { students to quieten } \\
\text { down }\end{array}$ & 82.5 & 87.8 & $5.3^{*}$ & 72.5 & 78.9 & $6.4^{*}$ \\
\hline $\begin{array}{l}\text { Students cannot work } \\
\text { well }\end{array}$ & 78.7 & 90.3 & $11.6^{*}$ & 81.5 & 87.1 & $5.6^{*}$ \\
\hline $\begin{array}{l}\text { Students don't start } \\
\text { working for a long } \\
\text { time after the lesson } \\
\text { begins }\end{array}$ & 77.1 & 87.4 & $10.3 *$ & 74.9 & 81.6 & $6.7 *$ \\
\hline
\end{tabular}

For teacher-student relation survey items, numbers shown in each cell represent the percentage of students agreeing or strongly agreeing with each given statement. For disciplinary climate survey items, numbers shown in each cell represent the percentage of students reporting that the event in each given statement happen "never or hardly ever" or "in some lessons"

$*$ The gains are statistically significant at the $p<.05$ level

math achievement. Korea recorded a modest gain, whereas the USA demonstrated slight declines in the percentage of students who reported that they do well in math. This direction of the change is consistent with expected policy outcomes. Nevertheless, the changes were small and their academic selfconcept gaps did not narrow much; the size of the USA-Korea gap dropped from 1.3 to 1 in a standard deviation unit. American students still remain much more confident about math performance than their Korean counterparts.

Finally, the analysis of PISA 2000-2009 student survey data, including teacher-student relations and school disciplinary climate variables, show that those changes were not necessarily consistent with expected directions or the changes were not big enough to close preexisting gaps between the two nations (see Table 3). At the baseline year of 2000, students in Korea reported much less positive teacher-student relations but slightly better school discipline than their American counterparts. The results of 2000-2009 student survey data analysis reveal more positive changes about teacher-student relations in Korea; the gaps of teachers' attention and support for students between the two countries have narrowed. On the other hand, the results do not support the expectation of relatively more positive changes regarding school disciplinary climate in the USA; the gap of safe and orderly learning climate relative to Korea has hardly changed.

\section{Conclusion}

For the past three decades, American policymakers have attempted to reform schools, partly to become more like high-performing East Asian nations such as Korea. Since then, graduation requirements have been raised, highstakes testing has been increased, and instructional time has grown. Meanwhile, schools in Korea made efforts to copy American counterparts that provide more student-centered and decentralized education opportunities. Education reform in Korea and the USA may be viewed as a balancing act. In both countries, however, a balance has yet to be achieved as school reform policy did not significantly change school practices and affect student outcomes. If we only measure the change based on policy discourse, reform agenda influenced both research and media topics. In spite of such changes in the policy language, however, only marginal or no changes were observed for student outcomes and school climates. There was little or no convergence in terms of narrowing the gaps between the USA and Korea in academic achievement (test scores and selfconcept) and school climate (student-teacher relations and student discipline). These findings support the new institutionalism perspective by suggesting that the national governments' reform policies may have led to symbolic institutional changes toward convergence between Korean and American education systems without impacting the technical core of their school organizations.

What are the major lessons we have learned about the process and outcome of international education policy benchmarking? The positive aspect of benchmarking is helping remove the mindset of "big frog in small pond" through cross-national comparison and learning. Through international comparisons of test results, Americans came to better realize that their students' average academic performance is mediocre relative to other developed nations. Through international comparisons of student survey results, Koreans also become more aware of their problems with relatively low student self-concept and poor school climate of engagement.

On the contrary, the risk of benchmarking is over-criticizing their own public schools from deficit views, 
demoralizing teachers, and ignoring or even undermining relative strengths of their current education system. In both countries, public schools were blamed for the broader problems and school teachers became the target of reform rather than catalyst for reform. The mentality of "the grass is greener on the other side of the fence" led to further erosion of public support for their own education system. Ironically, the two countries attempted to benchmark each other's system, when each country's own school system was faced with fierce criticisms and public calls for changes.

Another danger of benchmarking is doing harms through casual or mindless benchmarking, when nations try to copy what others are doing without full consideration of the cultural and institutional differences. The mind-set of "one size fits all" does not consider the risk that something that helps one nation can damage another. Both countries experienced unintended negative consequences of borrowing an extreme practice from each other; high-stakes testing policy is such an example in the USA, while testfree college admissions policy is such an example in Korea. It is insufficient to assume that because a successful nation uses a certain practice, it is the reason for the country's success, especially, economic prosperity. Educational practices work as systems, so borrowing individual practices seldom work. Further, each nation has its own unique culture and institution, and thus, benchmarking can work better when a newly introduced policy and practice is a right fit for the system. While globalization forces give constant pushes for international benchmarking efforts based on the global standards of best practice, each nation needs adaptive strategies to make its own unique education system more distinctive as well.

\section{References}

Baker, D. P. (2003). Should we be more like them? Reflections on causes of cross-national high school achievement differences and implications for American educational reform policy. In D. Ravitch (Ed.), Brookings papers on education policy (pp. 309-325). Washington, DC: Brookings Institution.

Bishop, J. (1998). Do curriculum-based external exit exam systems enhance student achievement? (CPRE research report RR-40) Philadelphia. PA: CPRE.

Bishop, J. (2001). A steeper, better road to graduation. Education Next. Retrieved October 6, 2005 http://www.educationnext.org/ 20014/index.html.

Cuban, L. (1992). What happens to reforms that last? The case of the junior high school. American Educational Research Journal, 29(2), 227-251.

Gahng, T. J. (1998). The context of education in Korea. In Paik, et al. (Eds.), Educational development in Korea: An analysis of investment and development strategies. Seoul, Korea: KEDI.
Gamoran, A. (2000). High standards: A strategy for equalizing opportunities for learning? In R. D. Kahlenberg (Ed.), A notion at risk: Preserving public education as an engine for social mobility (pp. 93-126). New York, NY: The Century Foundation.

Gamoran, A., \& Dreeben, R. (1986). Coupling and control in educational organizations. Administrative Science Quarterly, 31, 612-632.

Huh, K. (1998). Curriculum development policies in Korea. In Paik, et al. (Eds.), Educational development in Korea: An analysis of investment and development strategies. Seoul: KEDI.

Kim, M. (2003). Teaching and learning in Korean classrooms: The crisis and the new approach. Asia Pacific Education Review, $4(2), 140-150$.

Kim, M., Chung, K., Park, S., \& Lim, J. (2010). A study on development of outcome model for admissions officer system and improvement policy. Korean Educational Development Institute Report, RR 2010-21-2.

Koppich, J. E., \& Guthrie, J. W. (1993).Examining contemporary education reform efforts in the United States. In Beare, H. \& Boyd, L. (Eds.).Restructuring schools: an international perspective on the movement to transform the control and performance of schools (Ch. 4). London: Falmer Press.

Lee, J. (2001). School reform initiatives as balancing acts: Policy variation and educational convergence among Japan, Korea, England and the United States. Education Policy Analysis Archives, 9(13). http://epaa.asu.edu/epaa/v9n13.html.

Meyer, J. W., Ramirez, F. O., Rubinson, R., \& Boli, J. (1979). The world educational revolution, 1950-1970. In J. W. Meyer \& W. R. Scott (Eds.), National development and the world system: Educational, economic and political change (pp. 1950-1970). Chicago, IL: University of Chicago Press.

Meyer, J. W., \& Rowan, B. (1978). The structure of educational organizations. In M. W. Meyer (Ed.), Environments and organizations. San Francisco, CA: Jossey-Bass.

Ministry of Education. (1997). 7th National Curriculum in the Primary/Secondary School. Ministry of Education, 1997-15.

Ministry of Education (1998a). Revised agenda of 2002 college entrance system. October 19, 1998.

Ministry of Education (1998b). Education vision 2002: Creating new school culture, October 21, 2998.

Moon, Y. L. (2007). Education reform and competency-based education. Asia Pacific Education Review, 8(2), 337-341.

Oh, J. (2011). High school diversification against educational equality: A critical analysis of neoliberal education reform in South Korea. Asia Pacific Education Review, 12(3), 381-392.

Ramirez, F. O., \& Boli, J. (1987). Global patterns of educational institutionalization. In G. W. Thomas, et al. (Eds.), Institutional structure: Constituting the state, society, and the individual. SAGE: Newbury Park.

Ravitch, D. (2010). The death and life of the great American school system: How testing and choice are undermining education. New York: Basic Books.

Rowan, B. (1982). Organizational structure and the institutional environment: The case of public schools. Administrative Science Quarterly, 27, 259-279.

Rowan, B., \& Miskel, C. G. (1999). Institutional theory and the study of educational organizations. In J. Murphy \& K. S. Louis (Eds.), Handbook of research on educational administration (pp. 359-384). San Francisco, CA: Jossey-Bass.

Si-gan-gwa-gong-gan-sa (1995). 5.31 education reform. Seoul: Sigan-gwa-gong-gan-sa.

Smith, M. S., \& O'Day, J. (1991). Putting the pieces together: Systemic school reform (CPRE Policy Brief, RB-06-4/91). New Brunswick, NJ: Consortium for Policy Research in Education. 